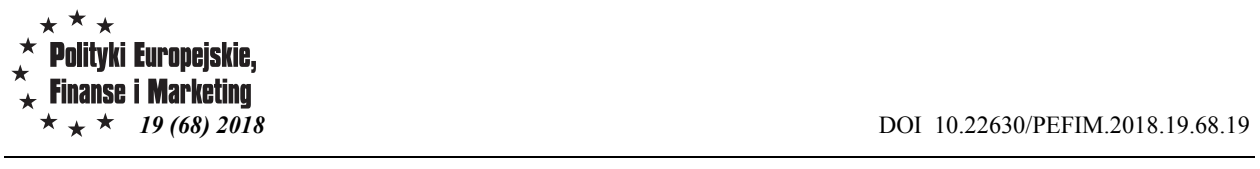

Agnieszka Siedlecka

Państwowa Szkola Wyższa im. Papieża Jana Pawla II w Bialej Podlaskiej

Mateusz Kuszneruk

Państwowa Szkoła Wyższa im. Papieża Jana Pawla II w Białej Podlaskiej

\title{
Zrównoważona konsumpcja a marnotrawstwo żywności w opinii kierowników gospodarstw domowych
}

\section{SUSTAINABLE CONSUMPTION AND WASTE OF FOOD IN THE OPINION OF HOUSEHOLD MANAGERS}

Celem artykułu jest wskazanie różnic $w$ podejściu do konsumpcji zrównoważonej oraz marnotrawstwa żywności wedlug deklarowanej postawy konsumpcyjnej. Dla jego realizacji określono pytania badawcze: Czy gospodarstwa domowe kierowane przez respondentów wyrażajacych opinię o zależności pomiędzy konsumpcja zrównoważona a stanem środowiska naturalnego zdecydowanie rzadziej wyrzucaja artykuły żywnościowe? Czy $w$ tego rodzaju gospodarstwach częściej decyzje nabywcze podejmowane sq racjonalnie?

Słowa kluczowe: gospodarstwo domowe, konsumpcja, konsumpcja zrównoważona, marnotrawstwo żywności

\section{Wstęp}

Kategoria zrównoważonej konsumpcji może być ujmowana w różnorodny sposób: jako alternatywny styl życia, ekokonsumpcja oraz ujęcie holistyczne ${ }^{1}$. W polskiej literaturze przedmiotu można znaleźć odniesienia do podejścia holistycznego, charakteryzującego się ujęciem zagadnienia konsumpcji zrównoważonej w kontekście społecznym i gospodarczym. W typowej literaturze europejskiej można mówić o ujęciu w kontekście ekokonsumpcji, gdzie konsumpcja zrównoważona identyfikowana jest jako trend ekologizacji konsumpcji. Koncepcja zrównoważonej konsumpcji zakłada, że konsumenci, wybierając sposób zaspokojenia potrzeby, biorą pod uwage szereg czynników, które zapewniają minimalizowanie negatywnych dla środowiska naturalnego i społeczeństwa skutków własnych decyzji zakupowych ${ }^{2}$. Ujęcie konsumpcji zrównoważonej jako stylu życia charakterystyczne jest przede wszystkim w literaturze USA, ujęcie to inspirowane jest głównie religiami Wschodu. ${ }^{3}$

1 Dąbrowska A., Bylok F., Janoś-Kresło M., Kiełczewski D., Ozimek I.: Kompetencje konsumentów. Innowacyjne zachowania. Zrównoważona konsumpcja. PWE, Warszawa 2015, s. 83.

2 Stefańska M., Śmigielska G.: Nowe wyzwania dla handlu detalicznego i marketingu - zrównoważona konsumpcja a innowacje przedsiębiorstw handlowych. Zeszyty Naukowe Szkoły Głównej Gospodarstwa Wiejskiego w Warszawie Polityki Europejskie, Finanse i Marketing, nr 16 (65) 2016, s. 87.

${ }^{3} \mathrm{Jw}$. 
Niezwykle ważną kwestią zarówno w kontekście konsumpcji zrównoważonej, jak także i świadomości ekologicznej jest racjonalne wykorzystywanie żywności. Problem marnotrawstwa żywności odnosi się nie tylko do gospodarstw domowych, ale można go również analizować $\mathrm{z}$ punktu widzenia producentów. Zmiany $\mathrm{W}$ procesach produkcyjnych, globalizacja wpłynęły w niektórych regionach światach na występowanie nadprodukcji żywności. Dlatego też wyróżnia się szereg przyczyn strat żywności wynikających między innymi $z^{4}$ :

- ubytków naturalnych (w wyniku przechowywania i w związku z tym zmian fizycznych i biochemicznych),

- strat wynikających z nieodpowiedniego gospodarowania artykułami spożywczymi (błędy w procesach produkcji, przetwórstwa, transporcie i magazynowaniu),

- marnotrawstwo (wynikające $\mathrm{z}$ nieprawidłowej dystrybucji, transportu, przechowywania, przygotowywania żywności przez przedsiębiorstwa i gospodarstwa domowe).

Jednym $z$ celów polityki żywnościowej jest osiągnięcie i utrzymanie bezpieczeństwa żywnościowego państwa. Według definicji FAO bezpieczeństwo żywnościowe to sytuacja gdzie wszyscy mają ciągły „fizyczny i ekonomiczny dostęp do wystarczającej ilości bezpiecznej i wartościowej żywności w celu zaspokojenia swoich potrzeb i preferencji żywieniowych do aktywnego i zdrowego życia"5. Bezpieczeństwo żywnościowe to nie tylko sam dostęp, ale także jakość oraz dostępność ekonomiczna i fizyczna do artykułów żywnościowych. Bezpieczeństwo żywnościowe ma trzy wymiary: międzynarodowy, w tym regionalny (np. Unii Europejskiej), państwowy (inaczej narodowy), gospodarstwa domowego, w tym indywidualny poszczególnych jego członków ${ }^{6}$.

Według danych szacunkowych Food and Agriculture Organization of the United Nations (FAO) z 2015 roku, liczba osób niedożywionych na całym świecie wynosiła 795 milionów osób. Z czego około 780 milionów osób to głodujący z krajów rozwijających się. W regionach tych odsetek osób niedożywionych spadł o 44,4\% w latach 1990-1992, a ogólny udział niedożywionych kształtuje się na poziomie $12,9 \%$ całej populacji i utrzymuje się na tym samym poziomie ${ }^{7}$. W przypadku krajów rozwiniętych obserwuje się potrójne obciążenie powodowane niedożywieniem ${ }^{8}$ :

1. niedożywienie pod względem dostarczanych kalorii, tzw. niedożywienie ilościowe,

\footnotetext{
${ }^{4}$ Śmiechowska M.: Zrównoważona konsumpcja a marnotrawstwo żywności. Ann. Acad. Med. Gedan. 2015, 45, s. 90

${ }^{5}$ Wspólna Polityka Rolna jako europejska polityka żywnościowa, Fundacja Programów Pomocy dla Rolnictwa Sekcja Analiz Ekonomicznych Polityki Rolnej, FAPA, Warszawa 2011, s. 3.

${ }^{6}$ Kapusta F.: Bezpieczeństwo żywnościowe Polski i jej mieszkańców w okresie przedakcesyjnym i po akcesji do Unii Europejskiej, Ekonomia XXI wieku. 4(12), 2016, s. 73.

${ }^{7}$ The State of Food Insecurity in the World. Meeting the 2015 international hunger targets: taking stock of uneven progress, FAO, Rome 2015, s. 17.

${ }^{8}$ Obiedzińska A.: Wybrane aspekty zapewnienia bezpieczeństwa żywnościowego w Unii Europejskiej, Studia BAS Nr 4(48) 2016, s. 125.
} 
2. niedożywienie spowodowane niedoborem mikroelementów (witamin, składników mineralnych), tzw. niedożywienie utajone - niedożywienie jakościowe,

3. niedożywienia związane jest $\mathrm{z}$ występowaniem nadwagi i otyłości oraz innych chorób związanych $\mathrm{z}$ nadkonsumpcją żywności, czyli nadmiernego jej spożycia.

Zagadnienie marnotrawstwa żywności zarówno w ujęciu mikro i makro ekonomicznym jest istotnym problem dlatego też stało się przedmiotem zainteresowania UE. Unia Europejska zakłada opracowanie do 2025 roku konkretnych działań mających na celu ograniczenie zjawiska o połowę. Działania te miały i mają być ukierunkowane zarówno na zjawisko marnotrawienia żywności jak i na zapobieganie powstawania odpadów żywności w procesach produkcji ${ }^{9}$. Skalę marnotrawstwa żywności obrazują dane statystyczne według których w 2012 roku w Unii Europejskiej marnotrawstwo żywności wynosiło $89 \mathrm{mln}$ ton, na jednego mieszkańca wielkość ta wynosiła $180 \mathrm{~kg}$. Największym „producentem” marnotrawionej żywności są gospodarstwa domowe (42\%). W Polsce na 1 mieszkańca rocznie marnotrawi się 235 kg żywności, gdzie w Austrii $207 \mathrm{~kg}$, Szwecji $227 \mathrm{~kg}^{10}$.

Federacja Polskich Banków Żywności wskazuje na 5 elementów w zakresie hierarchii postępowania $\mathrm{z}$ odpadami żywności. Można w jej obszarze wyróżnić dwa elementy: zapobieganie odpadom oraz zarządzanie odpadami ${ }^{11}$. Artykuł 17 Ustawy z dnia 14 grudnia 2012 o odpadach wyodrębnia następującą hierarchię sposobów postępowania z odpadami: zapobieganie powstawaniu odpadów, przygotowywanie do ponownego użycia, recykling, inne procesy odzysku, unieszkodliwianie ${ }^{12}$.

Alternatywnym stylem życia związanym $\mathrm{z}$ dbałością w sposób pośredni $\mathrm{o}$ ograniczanie marnotrawstwa żywności jest freeganizm. Sam termin freeganizm jest połączeniem dwóch terminów free (wolny, darmowy) i vegan (wegański). Wykreowanie się freeganizmu szacowane na lata 80 . XX wieku, związane było ze specyficznym stylem zachowania pewnej grupy mieszkańców USA, którzy pomimo wysokiego poziomu dochodów oraz korzystnego status społecznego, pozyskiwali artykuły żywnościowe, jak i nieżywnościowe ze śmietników ${ }^{13}$. Freeganizm opiera się na stwierdzeniu, że zarówno kapitalizm jak i masowa produkcja opierają się na wyzysku pracowników, zwierząt i środowiska naturalnego. Taki kierunek konsumpcji postrzegany jest jako antykonsumpcyjny styl życia. Odnosi się zarówno do produktów

\footnotetext{
${ }^{9}$ Dąbrowska A., Janoś-Kresło M.: Marnowanie żywności jako problem społeczny. Handel Wewnętrzny 2013, 4(345), s. 14.

${ }^{10}$ Kwasek M.: Zrównoważona konsumpcja żywności sposobem na zmniejszenie

marnotrawstwa żywności, dostęp z dnia 14 luty 2017 https://www.ierigz.waw.pl/download/19559dr_hab._M._Kwasek.pdf

${ }_{11}$ Raport Federacji Polskich banków Żywności. Zapobieganie marnowaniu żywności z korzyścią dla społeczeństwa, Warszawa 2013, s. 7.

${ }^{12}$ Ustawy z dnia 14 grudnia 2012 o odpadach, Dz.U. 2013 poz. 21, z póź. zmianami.

${ }^{13}$ Bąk T.: Freeganizm jako subkultura i zjawisko nowych wartości w zglobalizowanym świecie. Edukacja Humanistyczna, nr 1 (30), 2014, s. 23.
} 
żywnościowych ale także konsumpcji takich dóbr jak odzież, obuwie, sprzęt elektroniczny ${ }^{14}$.

\section{Metodyka badań}

Celem artykułu jest wskazanie różnic w podejściu do konsumpcji zrównoważonej oraz marnotrawstwa żywności według deklarowanej postawy konsumpcyjnej. Dla jego realizacji określono pytania badawcze: Czy gospodarstwa domowe kierowane przez respondentów wyrażających opinię o zależności pomiędzy konsumpcją zrównoważoną a stanem środowiska naturalnego zdecydowanie rzadziej wyrzucają artykuły żywnościowe? Czy w tego rodzaju gospodarstwach częściej decyzje nabywcze podejmowane są racjonalnie?

Dla realizacji celu przeprowadzone zostały badania ankietowe na grupie 100 kierowników gospodarstw domowych ${ }^{15}$. Dobór próby do badań przeprowadzony został z wykorzystaniem metody doboru nielosowego (nieprobabilistycznego). Badania prowadzone były w okresie kwiecień-czerwiec 2016r. Wyniki badań poddane zostały analizie z wykorzystaniem programu statystycznego SPSS. Przeprowadzona została analiza danych $\mathrm{z}$ wykorzystaniem statystyk opisowych: średnia $\mathrm{i}$ odchylenie standardowe oraz testu niezależności chi-kwadrat.

Badaną grupę kierowników gospodarstw domowych stanowiły w 51\% kobiety. Zdecydowana większość respondentów to osoby z wyższym wykształceniem: 35\% wyższe licencjackie, 32\% wyższe magisterskie i 9\% wyższe inżynierskie. Pozostali respondenci zadeklarowali wykształcenie średnie (19\%) i zasadnicze zawodowe (5\%). Przeważająca część badanych kierowników gospodarstw to osoby mieszkające w mieście. Jedynie $20 \%$ respondentów to głowy gospodarstw $\mathrm{z}$ tereny obszarów wiejskich. Zdecydowaną większość badanych stanowili mieszkańcy miast o ogólnej liczbie ludności od 50000 do 100000 mieszkańców. Mieszkańcy miast do 50000 osób stanowili jedynie $9 \%$ badanej grupy. Badana grupa zarządzających gospodarstwami domowymi charakteryzowała się zróżnicowaniem pod względem wieku. Średni wiek wynosił 30,97, przy odchyleniu standardowym 9,57.

\section{Potrzeby żywnościowe jako wiodące potrzeby badanych gospodarstw}

Nabywanie artykułów żywnościowych ściśle skorelowane jest $\mathrm{z}$ dążeniem do zaspokajania podstawowych potrzeb człowieka. Pojęcie potrzeby rozumiane jest w literaturze przedmiotu jako stan braku i dążenie do jego zaspokojenia, co jest równoznaczne $z$ wytyczeniem określonego celu działania ${ }^{16}$. Problematyka zaspokajania potrzeb wiąże się z zagadnieniem jakości życia, z tym, że jakość życia jest pojęciem

\footnotetext{
${ }^{14}$ Zalega T.: Freeganizm - nowy trend konsumencki w zachowaniach nabywczych miejskich gospodarstw domowych w Polsce w okresie kryzysu (wyniki badań). Zarządzanie innowacyjne w gospodarce i biznesie, $\mathrm{nr}$ $1(16) / 2013$, s. 102

${ }^{15}$ Kierownik gospodarstwa domowego rozumiany jest jako osoba dostarczająca w całości lub znaczącej częśsi dochody dla gospodarstwa a także podejmująca decyzje w zakresie wydatkowania środków finansowych, synonimem określenia jest termin głowa gospodarstwa domowego.

${ }^{16}$ Dach Z. (red.): Wprowadzenie do ekonomii. Wydawnictwo Akademii Ekonomicznej w Krakowie, Kraków 1999, s. 32.
} 
zdecydowanie szerszym obejmuje bowiem szereg innych obszarów ${ }^{17}$. Jednakże ilość i różnorodność potrzeb odczuwanych przez człowieka jest bardzo duża.

Spożywanie żywności jest podstawowym warunkiem życia ludzkiego organizmu. Zaspokajanie potrzeby głodu związane jest $\mathrm{z}$ zaspokajaniem podstawowych potrzeb fizjologicznych człowieka. Należy także pamiętać, że żywność jest dobrem nie posiadającym substytutów i bez względu na poziom osiaganych dochodów w gospodarstwie domowym, wydatki na żywność stanowić będą priorytet ${ }^{18}$.

Analizując potrzeby badanych gospodarstw domowych można zaobserwować, iż zdecydowanie najważniejsze potrzeby konsumpcyjne w opinii kierowników gospodarstw domowych stanowią potrzeby żywnościowe. Respondenci dokonując oceny ważności poszczególnych potrzeb dla gospodarstw domowych wykorzystywali skale od 1 do 5 , gdzie 1 oznaczało absolutnie nie ważną potrzebę, zaś 5 bardzo ważną. W takiej ocenie potrzeby związane z zaspokajaniem głodu zostały ocenione najwyżej - średnia 4,86 (odchylenie standardowe 0,40 ) - wykres 1 .

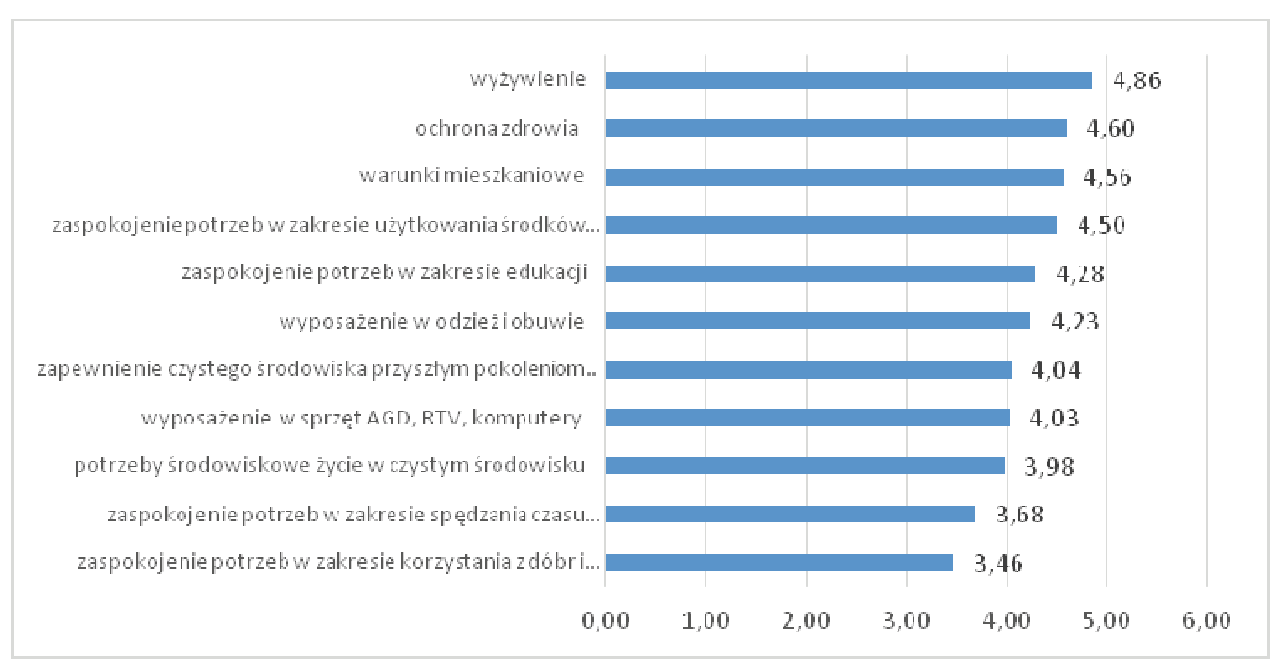

Wykres 1. Średnia ocena ważności potrzeb konsumpcyjnych dla gospodarstw domowych w ocenie ich kierowników*

*- ocena w skali od 1 do 5 , gdzie 1 oznaczało absolutnie nie ważną potrzebę, zaś 5 bardzo ważną Źródło: Opracowanie własne na podstawie wyników badań.

Zmiany w profilu społeczno-demograficznym gospodarstw domowych są istotnym czynnikiem w kształtowania się popytu na żywność. Na kształtowanie się poziomu dochodów, a tym samym preferencji związanych z konsumpcją wpływają takie czynniki jak liczba osób w gospodarstwie, jego typ biologiczny, miejsce zamieszkania czy też

\footnotetext{
${ }^{17}$ Siedlecka A.: Impact of the activities of local government on the quality of life of households, in the opinion of the inhabitants, of the border commune, Hanna, Miscellanea Geographica. Volume 19, Issue 4, p.21.

${ }^{18}$ Zalega T.: Spożycie żywności w gospodarstwach domowych z osobami bezrobotnymi w województwie mazowieckim. Zeszyty Naukowe SGGW w Warszawie. Ekonomika i Organizacja Gospodarki Żywnościowej, 2011, nr 93, s. 120.
} 
wykształcenie członków gospodarstwa ${ }^{19}$. Można również wskazać, iż takim czynnikiem jest także grupa społeczno-gospodarcza gospodarstwa domowego. Dane pochodzące z badań budżetów 1566 gospodarstw domowych w roku 2016 wskazują na znaczące różnice w spożyciu wybranych grup artykułów żywnościowych przez gospodarstwa. Można powiedzieć o kształtowaniu się nowych wzorców konsumpcji zbliżonych dla gospodarstw domowych rencistów, emerytów i rolników. Gospodarstwa te charakteryzują się zdecydowanie wyższym średnim spożyciem pieczywa i produktów zbożowych, jaj, warzyw czy mięsa w porównaniu z pozostałymi gospodarstwami (tabela 1). W przypadku średniego miesięcznego spożycie pieczywa na 1 osobę $\mathrm{W}$ gospodarstwach domowych rolników wielkość ta wynosiła 4,51 kg, zaś w gospodarstwach domowych pracujących na własny rachunek $2,81 \mathrm{~kg}$. Również średnie spożycie mleka jest wyższe w gospodarstwach rolników (4,09 1), niż w gospodarstwach pracujących na własny rachunek $(2,641)$.

Tabela 1. Średnie miesięczne spożycie wybranych artykułów żywnościowych na 1 osobę w gospodarstwach domowych według grup społeczno-ekonomicznych w roku 2016.

\begin{tabular}{|l|c|c|c|c|c|c|c|}
\hline & ogółem & $\begin{array}{c}\text { pracowników } \\
\text { na } \\
\text { stanowiskach } \\
\text { robotniczych }\end{array}$ & $\begin{array}{c}\text { pracowników } \\
\text { na } \\
\text { stanowiskach } \\
\text { nierobotniczych }\end{array}$ & rolników & $\begin{array}{c}\text { pracujących } \\
\text { na własny } \\
\text { rachunek }\end{array}$ & emerytów & rencistów \\
\hline $\begin{array}{l}\text { pieczywo i } \\
\text { produkty } \\
\text { zbożowe } \\
\text { ogółem w kg }\end{array}$ & 5,88 & 5,57 & 5,16 & 6,99 & 4,96 & 7,25 & 7,47 \\
\hline ryż w kg & 0,16 & 0,14 & 0,16 & 0,13 & 0,15 & 0,20 & 0,23 \\
\hline $\begin{array}{l}\text { pieczywo } \\
\text { w kg }\end{array}$ & 3,52 & 3,52 & 2,91 & 4,51 & 2,81 & 4,22 & 4,45 \\
\hline $\begin{array}{l}\text { makaron i } \\
\text { produkty } \\
\text { makaronowe } \\
\text { w kg }\end{array}$ & 0,38 & 0,34 & 0,36 & 0,36 & 0,33 & 0,45 & 0,48 \\
\hline $\begin{array}{l}\text { płatki } \\
\text { śniadaniowe } \\
\text { w kg }\end{array}$ & 0,14 & 0,13 & 0,18 & 0,10 & 0,17 & 0,13 & 0,13 \\
\hline $\begin{array}{l}\text { mięso ogółem } \\
\text { w kg }\end{array}$ & 5,32 & 5,06 & 4,47 & 6,21 & 4,45 & 6,88 & 6,76 \\
\hline $\begin{array}{l}\text { mięso surowe } \\
\text { w kg }\end{array}$ & 3,04 & 2,84 & 2,54 & 3,79 & 2,63 & 3,97 & 3,84 \\
\hline $\begin{array}{l}\text { wędliny i inne } \\
\text { przetwory w } \\
\text { kg }\end{array}$ & 2,03 & 2,00 & 1,76 & 2,14 & 1,71 & 2,51 & 2,54 \\
\hline $\begin{array}{l}\text { ryby i owoce } \\
\text { morza w kg }\end{array}$ & 0,32 & 0,25 & 0,31 & 0,31 & 0,31 & 0,48 & 0,40 \\
\hline mleko w 1 & 3,08 & 2,82 & 2,78 & 4,09 & 2,64 & 3,68 & 3,73 \\
\hline jaja w szt. & 11,64 & 10,40 & 10,23 & 14,30 & 9,93 & 15,17 & 14,97 \\
\hline $\begin{array}{l}\text { oleje i } \\
\text { tuszcze w kg }\end{array}$ & 1,13 & 1,08 & 0,93 & 1,21 & 0,91 & 1,53 & 1,53 \\
\hline owoce w kg & 3,66 & 2,80 & 3,97 & 3,16 & 3,75 & 4,90 & 4,16 \\
\hline
\end{tabular}

${ }^{19}$ Gałązka M.: Społeczno-demograficzne uwarunkowania kształtowania się wydatków żywnościowych w gospodarstwach domowych w Polsce. Rocz. Nauk Rol., seria G, t. 100, z. 1, 2013, s. 23-24. 


\begin{tabular}{|l|c|c|c|c|c|c|c|}
\hline $\begin{array}{l}\text { warzywa } \\
\text { w kg }\end{array}$ & 8,59 & 7,89 & 7,32 & 10,53 & 7,24 & 11,26 & 11,25 \\
\hline cukier w kg & 1,01 & 0,95 & 0,73 & 1,67 & 0,70 & 1,38 & 1,42 \\
\hline $\begin{array}{l}\text { woda } \\
\text { mineralna i } \\
\text { źródlana w 1 }\end{array}$ & 4,91 & 4,16 & 5,93 & 3,45 & 5,43 & 5,26 & 4,57 \\
\hline $\begin{array}{l}\text { soki owocowe } \\
\text { i warzywne w } \\
\text { 1 }\end{array}$ & 0,97 & 0,87 & 1,26 & 0,65 & 1,24 & 0,77 & 0,71 \\
\hline
\end{tabular}

Źródło: Opracowanie własne na podstawie Budżety gospodarstw domowych w 2016r. Informacje i opracowania statystyczne, Główny Urząd Statystyczny, Warszawa 2017, s. 179-181.

Drugą równie wysoko ocenioną pod względem ważności potrzebą w badanych gospodarstwach domowych była ochrona zdrowia (średnia 4,60; odchylenie standardowe 0,68 ). Ochrona zdrowia rozumiana jako zarówno proces leczenia jak i zakup środków medycznych. Ochrona zdrowia jako jeden z elementów usług publicznych jest jednym z czynników wpływających na standard i jakość życia społeczeństwa. Biorąc pod uwagę zmiany struktury demograficznej polskiego społeczeństwa, wzrost liczby osób w wieku poprodukcyjnym to wydatki te wzrastają zarówno w ujęciu makroekonomicznym, jak także w poszczególnych gospodarstwach domowych. Według metodologii GUS w wydatkach tych mieszczą się wydatki na wyroby medyczno-farmaceutyczne, urządzenia i sprzęt medyczny (np. leki, zielarskie produkty farmaceutyczne, materiały chirurgiczne i opatrunkowe), usługi ambulatoryjne i inne usługi związane ze zdrowiem (np. opłaty za: porady lekarskie, zdjęć rentgenowskich, USG, usługi dentystyczne, analizy laboratoryjne) oraz usługi szpitalne i sanatoryjne (np. opłaty administracyjne związane $\mathrm{z}$ leczeniem szpitalnym, opłaty związane $\mathrm{z}$ leczeniem sanatoryjnym, w zakładach rehabilitacyjnych) ${ }^{20}$. Przeciętne miesięczne rozchody na 1 osobę w gospodarstwach domowych klasyfikowane jako wydatki na zdrowie w latach 2006-2016 wskazują tendencje wzrostowe. Na przestrzeni 10 lat nastąpił wzrost tych wydatków o 60\%. Co można rozumieć w dwojaki sposób. Po pierwsze jako zmniejszenie dostępu do usług medycznych i wokół medycznych - przez co gospodarstwa ponoszą wyższe koszty. Bądź też jako wzrost całkowitych kosztów na rynku tego rodzaju usług.

20 Budżety gospodarstw domowych w 2016r. Informacje i opracowania statystyczne. Główny Urząd Statystyczny, Warszawa 2017, s. 284. 


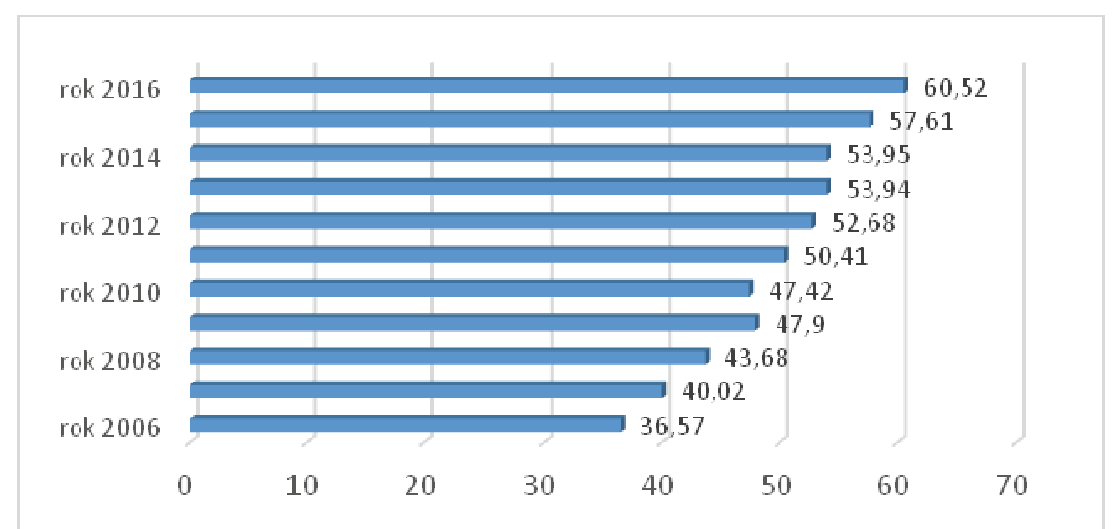

Wykres 2. Przeciętne miesięczne rozchody na 1 osobę w gospodarstwach domowych na wydatki na zdrowie w latach 2006-2016.

Źródło: Opracowanie własne na podstawie Budżety gospodarstw domowych w latach 2006-2016, Główny Urząd Statystyczny, Warszawa w kolejnych latach.

Analizując zmiany poziomu przeciętnych miesięcznych rozchodów na 1 osobę w gospodarstwach domowych klasyfikowane jako wydatki na zdrowie można zaobserwować, iż z roku na rok wartość ta wzrastała (poza rokiem 2010), różna była jedynie skala tych zmian.

Warto zwrócić uwagę na fakt, iż zgodnie z piramidą potrzeb A. Maslova potrzeby klasyfikujące się jako najwyżej umiejscowione to potrzeby związane z samorealizacją między innymi potrzeby kulturalne. W opinii badanych na potrzeby artykułu respondentów jako najmniej ważne w realizacji wskazane zostały potrzeby w zakresie korzystania z dóbr i usług kulturalnych (kino teatr książki, gazety itp.)-średnia ocena ważności 3,46, przy odchyleniu standardowym 0,92 .

\section{Marnotrawstwo żywności}

Koncentrując się jednakże na potrzebie podstawowej, jaką jest zaspokojenie potrzeby głodu poprzez dostarczenie odpowiedniej ilości i jakości żywności należy wskazać, iż nie we wszystkich gospodarstwach zakupy te są racjonalne. W badanych gospodarstwach pojawiła się nadwyżka żywności, która nie była konsumowana w gospodarstwie. Wśród badanych kierowników gospodarstw domowych jedynie $32 \%$ wskazało, iż nadwyżkę produktów spożywczych, których nie jest w stanie racjonalnie wykorzystać oddaje rodzinie, znajomym czy potrzebującym. Ponad $60 \%$ biorących udział w badaniu ankietowym wskazało, iż nadwyżka żywności wyrzucana jest do śmieci. Zbliżone wyniki uzyskała B. Bilska wraz z zespołem w swoich badaniach. W grupie ponad 200 osób przebadanych w województwie mazowieckim pod kątem gospodarowania żywnością na przełomie roku 2014/2015 - 62\% przyznała, iż wyrzuca żywność ${ }^{21}$.

${ }^{21}$ Bilska B., Grzesińska W., Tomaszewska M., Rudziński M.: Marnotrawstwo żywności jako przykład nieefektywnego zarządzania w gospodarstwach domowych. Stowarzyszenie Ekonomistów Rolnictwa i Agrobiznesu, Roczniki Naukowe, Tom XVII, Zeszyt 4, s. 40. 
Analizując zmienne społeczno-ekonomiczne mogące mieć wpływ na racjonalne wykorzystywanie nadmiernych zakupów artykułów żywnościowych można wskazać, iż istotna statystycznie zależność wystąiła jedynie pomiędzy płcią a decyzją o oddaniu nadmiaru żywności lub jej wyrzuceniu ( $\mathrm{p}=0,004$; chi-kwadrat 8,206 ). Kobiety zdecydowanie częściej oddawały nadmiar żywności rodzinie, znajomym $(45,1 \%) \mathrm{w}$ porównaniu $\mathrm{z}$ mężczyznami $(18,4 \%)$. Nie zaobserwowano natomiast istotnych statystycznie różnic pomiędzy faktem rozdysponowania nadmiaru żywności a poziomem wykształcenia kierowników gospodarstwa domowego $(\mathrm{p}=0,104)$. Jak również zależność taka nie wystapiła $\mathrm{w}$ odniesieniu do średnich miesięcznych dochodów netto na jedną osobę $w$ gospodarstwie domowym $(\mathrm{p}=0,662)$. Należy jednak zaznaczyć, iż w przypadku tej cechy można zaobserwować, iż gospodarstwa deklarujące wyższy poziom dochodów częściej przekazują nadmiar żywności innym (np.: rodzinie, znajomym).

Również nie można mówić o wystapieniu istotnej statystycznie zależności pomiędzy zwyczajową formą nabywania artykułów żywnościowych a faktem występowania marnotrawstwa żywności i wykorzystywania nadwyżek żywności $(\mathrm{p}=0,818)$. Blisko $60 \%$ respondentów robiła zakupy raz na kilka dni lub nawet rzadziej, dokupując brakujące produkty (41\%) lub nie uzupełniając ich (16\%). Niespełna co trzeci badany kierownik gospodarstwa domowego wskazal, iż robi zakupy tak aby nie kupować na zapas. Metody robienia zakupów wśród respondentów mogą wiązać się z częstotliwością dokonywania zakupów w różnych miejscach. Respondenci zadeklarowali, iż najczęściej artykuły żywnościowe nabywają w super i hiper marketach - średnia $5,25^{22}$. W przypadku małych sklepów osiedlowych, które charakteryzują się bliskim kontaktem ze sprzedawca, brakiem możliwości długiego oglądania towarów, zastanawiania się wielkość tak kształtowała się na poziomie 3,90. Sposób robienia zakupów wiąże się pośrednio z motywami marnotrawstwa artykułów spożywczych. Analizując powody wyrzucania żywności do śmieci można wskazać, iż najczęściej jest to przekroczenie terminu spożycia $(86 \%)$ a także przygotowywanie zbyt dużych porcji $(32 \%)$. Również niska jakość produktów spożywczych $(22 \%)$ oraz niewłaściwe ich przechowywanie stanowiło czynniki, które wpływały na fakt marnotrawstwa żywności.

\section{Konsumpcja zrównoważona a marnotrawstwo żywności}

Idea, która w znaczący sposób mogłaby wpływać na kreowanie się nowych postaw wśród konsumentów jest idea konsumpcji zrównoważonej. Czyli konsumpcji, która „oznacza taki sposób korzystania $\mathrm{z}$ dóbr materialnych i usług, który zapewnia konsumentom lepszą jakość życia, a równocześnie nie degraduje środowiska i nie zagraża konsumpcji przyszłych pokoleń. ${ }^{23}$ Kreowanie świadomości ekologicznej poszczególnych członków gospodarstw domowych o zagrożeniach jakie niesie brak dbałości o środowisko przyrodnicze jest niezwykle ważne z punktu widzenia wdrażania koncepcji rozwoju zrównoważonego. Problem nadmiernej konsumpcji jest jednym z działań które powinny być podejmowane zarówno na szczeblu edukacji szkolnej jak także i kształcenia ustawicznego.

\footnotetext{
${ }^{22}$ Ocena w skali od 1 do 6 , gdzie 1 oznaczało nigdy nie robię zakupów w super i hipermarketach, zaś 6 bardzo często robię zakupy w hiper i super marketach.

${ }^{23}$ Czubała A.: Rola konsumentów w realizacji koncepcji społecznej odpowiedzialności przedsiębiorstw. Konsumpcja i rozwój, nr 1/2011, s. 62.
} 
Respondenci zapytani o wyrażenie opinii czy: stan środowiska naturalnego wymaga podejmowania zachowań proekologicznych oraz działań związanych z konsumpcją zrównoważona, stwierdzili, iż proekologiczne zachowania konsumentów oraz konsumpcja zrównoważona przyczyniają się do poprawy stanu środowiska naturalnego oraz, że poprawa stanu środowiska naturalnego nie jest możliwa bez odpowiedniej edukacji ekologicznej. W zdecydowanej większości byli zgodni z przedstawionymi stwierdzeniami - tabela 2. Jednakże fakt, zgadzania się z nimi nie zawsze wiąże się z realizowanymi działaniami. Ponad $70 \%$ kierowników gospodarstw zgodziło się ze stwierdzeniem, iż stan środowiska wymaga działań i zachowań o charakterze proekologicznym a także realizacji założeń konsumpcji zrównoważonej. Jednakże pytając o to czy w gospodarstwie dochodzi do wyrzucania żywności do śmieci 65\% respondentów w tej grupie daje odpowiedź twierdzącą. Oznacza to, że sam fakt posiadania świadomości pewnych zdarzeń, zachowań nie jest jednoznaczny $\mathrm{z}$ ich realizacją.

Tabela 2. Opinia respondentów w zakresie stwierdzeń związanych z konsumpcją zrównoważoną a odsetek gospodarstw deklarujących wyrzucanie żywności do śmieci

\begin{tabular}{|c|c|c|c|c|c|c|}
\hline \multirow[t]{2}{*}{ Stwierdzenia } & \multicolumn{3}{|c|}{ Opinie respondentów (w \%) } & \multicolumn{3}{|c|}{$\begin{array}{l}\text { \% gospodarstw wyrzucających } \\
\text { żywność do śmieci w } \\
\text { poszczególnych grupach } \\
\text { wyrażających opinie o badanych } \\
\text { stwierdzeniach }\end{array}$} \\
\hline & $\begin{array}{l}\text { Tak - } \\
\text { zgadzam } \\
\text { się ze } \\
\text { stwierdz } \\
\text { eniem } \\
\end{array}$ & $\begin{array}{l}\text { Ani się } \\
\text { zgadzam } \\
\text {, ani się } \\
\text { nie } \\
\text { zgadzam }\end{array}$ & $\begin{array}{l}\text { Nie } \\
\text { zgadzam } \\
\text { się ze } \\
\text { stwierdz } \\
\text { eniem } \\
\end{array}$ & $\begin{array}{l}\text { Tak - } \\
\text { zgadzam } \\
\text { się ze } \\
\text { stwierdz } \\
\text { eniem } \\
\end{array}$ & $\begin{array}{l}\text { Ani się } \\
\text { zgadzam } \\
\text {, ani się } \\
\text { nie } \\
\text { zgadzam }\end{array}$ & $\begin{array}{l}\text { Nie } \\
\text { zgadzam } \\
\text { się ze } \\
\text { stwierdz } \\
\text { eniem }\end{array}$ \\
\hline $\begin{array}{l}\text { (1) stan środowiska } \\
\text { naturalnego wymaga } \\
\text { podejmowania zachowań } \\
\text { proekologicznych oraz } \\
\text { działań związanych z } \\
\text { konsumpcją zrównoważoną }\end{array}$ & 75 & 18 & 7 & 65,3 & 66,7 & 100 \\
\hline $\begin{array}{l}\text { (2) proekologiczne } \\
\text { zachowania konsumentów } \\
\text { oraz konsumpcja } \\
\text { zrównoważona przyczyniają } \\
\text { się do poprawy stanu } \\
\text { środowiska naturalnego }\end{array}$ & 69 & 19 & 12 & 62,3 & 68,4 & 100 \\
\hline $\begin{array}{l}\text { (3) poprawa stanu } \\
\text { środowiska naturalnego nie } \\
\text { jest możliwa bez } \\
\text { odpowiedniej edukacji } \\
\text { ekologicznej }\end{array}$ & 63 & 19 & 18 & 61,9 & 73,7 & 83,3 \\
\hline
\end{tabular}

Źródło: Opracowanie własne na podstawie wyników badań.

Zdecydowanie bardziej konsekwentna w swoich działaniach była grupa gospodarstw w przypadku których kierownik nie zgadzał się $\mathrm{z}$ prezentowanymi stwierdzeniami. Zarówno w przypadku stwierdzenia 1 i 2 - wszyscy respondenci jednocześnie zadeklarowali, iż w ich gospodarstwach żywność jest wyrzucana. 
Dokonując kategoryzacji wszystkich gospodarstw domowych z uwzględnieniem parametru deklarowanej postawy konsumenckiej względem środowiska przyrodniczego skonstruowanego na bazie trzech zmiennych uzyskanych $\mathrm{z}$ opinii kierowników gospodarstw domowych ${ }^{24}$ wyodrębnione zostały trzy grupy gospodarstw charakteryzujące się postawą obojętna względem środowiska, nieskrajną i prośrodowiskową ${ }^{25}$. Odnosząc się do stosowania metod wykorzystywania nadmiaru żywności i artykułów żywnościowych w poszczególnych grupach gospodarstw według deklarowanej postawy konsumenckiej z uwzględnieniem problematyki środowiska przyrodniczego można zaobserwować, iż kierownicy o postawie nieskrajnej i prośrodowiskowej zdecydowanie rzadziej wskazywali, iż wyrzucają żywności do śmieci (tabela 3).

Tabela 3. Decyzje związane $\mathrm{z}$ wykorzystaniem żywności a postawa względem środowiska przyrodniczego

\begin{tabular}{|l|c|c|c|c|}
\hline \multirow{2}{*}{ Wyszczególnienie } & \multirow{2}{*}{ Ogółem } & \multicolumn{3}{|c|}{ Postawa } \\
\cline { 3 - 5 } & 32,0 & 13,3 & 34,9 & 48,1 \\
\hline $\begin{array}{l}\text { nadwyżkę produktów } \\
\text { spożywczych oddaję (np.: } \\
\text { rodzinie, znajomym) }\end{array}$ & 68,0 & 86,7 & 65,1 & 51,9 \\
\hline $\begin{array}{l}\text { nadwyżkę żywności } \\
\text { wyrzucam do śmieci }\end{array}$ & 3 & nieskrajna & prośrodowiskowa \\
\hline
\end{tabular}

Źródło: opracowanie własne na podstawie wyników badań.

Niepokojące jest zjawisko wskazujące, iż w przypadku gospodarstw domowych którymi kierowali respondenci deklarujący obojętne stanowisko względem środowiska przyrodniczego $\mathrm{w}$ trakcie realizacji zakupów wystapiła tak duża grupa wskazująca, iż żywność wyrzucana jest do śmieci - 86,7\%. Uzyskane dane pozwalają przypuszczać, iż podstawa kierownika gospodarstwa domowego względem środowiska przyrodniczego, a także poziom świadomości ekologicznej w pewnym stopniu wpływają na dążenie do konsumpcji zrównoważonej, równoważne także $\mathrm{z}$ ograniczaniem marnotrawstwa żywności.

Analizując artykuły spożywcze, które najczęściej są wyrzucane w gospodarstwach domowych respondentów wymieniano najczęściej: jogurty (55\%), pieczywo (46\%), mleko (36\%), wędliny (34\%) oraz owoce (31\%).

Przeprowadzone przez M. Cieślińska i B. Kowrygo badania dotyczące zachowań konsumentów na rynku produktów mleczarskich wskazały, iż produktami mlecznymi najczęściej nabywanymi przez konsumentów są między innymi jogurty, kefiry, serki homogenizowane. Blisko 3/4 badanych przez autorki respondentów wskazało, iż nabywa jogurty zawsze, bardzo często i często ${ }^{26}$. Jak wskazują badania przeprowadzone na

${ }^{24}$ W konstrukcji parametru deklarowanej postawy wykorzystano opinie respondentów na następujące stwierdzenia czy: w codziennych decyzjach konsumenckich kierują się troską o środowisko przyrodnicze, a także czy znają podstawowe jego problemy; zwracają uwagę na wpływ jaki wywierają na środowisko przyrodnicze kupowane przez nich produkty; wybierając dostawcę usług sugerują się jego stosunkiem do środowiska przyrodniczego i czy ważny jest fakt, że dostawca usług korzysta z produktów i urządzeń przyjaznych środowisku.

${ }^{25}$ Siedlecka A.: Sustainable Consumption as a Behaviour Model of Households. Economic Science for Rural Development Conference Proceedings, No 45, 2017.

${ }^{26}$ Cieślińska M., Kowrygo B.: Budowanie pozycji rynkowej i zdobywanie przewagi konkurencyjnej na przykładzie Danone sp. z o.o. Handel Wewnętrzny 2013,4(345), s. 6. 
grupie 117 punktów sprzedaży zlokalizowanych na terenie województwa mazowieckiego i podkarpackiego najczęstszą przyczyną marnotrawstwa mleka i jego przetworów $\mathrm{w}$ handlu detalicznym jest przekroczenie terminu przydatności do spożycia $^{27}$. Można przypuszczać, że również w przypadku gospodarstw domowych jest to główny powód wyrzucania tego rodzaju artykułów. Nie racjonalne zakupy, które są realizowane powoduja, iż $\mathrm{w}$ efekcie gospodarstwa zmuszone są do ponoszenia tego rodzaju strat.

Drugą grupą produktów najczęściej wyrzucanych w gospodarstwach domowych respondentów było pieczywo. Według danych Głównego Urzędu Statystycznego przeciętne miesięczne spożycie pieczywa w gospodarstwach domowych rokrocznie spada. W roku 2013 wielkość ta wynosiła 4,13kg, 2014 - 3,94 kg, zaś w roku 2015 - już jedynie $3,74 \mathrm{~kg}^{28}$. Pomimo, że czerstwe pieczywo pozytywnie oddziałuje na zdrowie jest wyrzucane, powodem jest głównie brak atrakcyjności sensorycznej dla konsumentów ${ }^{29}$. Nie we wszystkich gospodarstwach domowych skala marnotrawstwa artykułów żywnościowych była taka sama. W gospodarstwach domowych gdzie kierownik charakteryzował się prośrodowiskowym modelem zachowań nabywczych zdecydowanie rzadziej dochodziło do wyrzucania żywności.

W gospodarstwach domowych kierowanych przez respondentów których postawa nabywcza charakteryzowała się obojętnością względem środowiska przyrodniczego zdecydowanie częściej dochodziło do marnotrawstwa wszystkich analizowanych grupach artykułów żywnościowych. Szczególnie tendencje te uwidaczniały się w przypadku pieczywa gdzie $60 \%$ kierowników gospodarstw wskazało na wyrzucanie tego artykułu, w pozostałych grupach gospodarstw były to wielkości zdecydowanie mniejsze. I tak dla przykładu w gospodarstwach gdzie kierownik charakteryzował się postawą prośrodowiskową wyrzucanie pieczywa występowało w $37 \%$ gospodarstw.

\section{Podsumowanie}

Problem racjonalnego wykorzystywania żywności jest zagadnieniem, które można analizować z perspektywy gospodarstwa domowego, gospodarki krajowej, światowej czy też w ujęciu globalnym. Każda $\mathrm{z}$ tych perspektyw wiąże się $\mathrm{z}$ faktem, iż marnotrawstwo żywności, nieumiejętne jej rozdysponowywanie to czynnik który w mniejszym bądź większym stopniu wpływa na stan środowiska przyrodniczego.

Dążenie do prowadzenia systemów gospodarczych zgodnie z paradygmatem rozwoju zrównoważonego wiąże się jednocześnie $\mathrm{z}$ wprowadzaniem zasad zrównoważonej konsumpcji, która stwarza możliwości zachowania walorów środowiska dla współczesnych i przyszłych pokoleń.

\footnotetext{
${ }^{27}$ Wrzosek M., Bilska B., Kołożyn-Rajewska D., Krajewski K., Kondraszuk A.: Określenie skali i przyczyn strat żywności w handlu detalicznym na przykładzie mleka i jego przetworów. Żywność. Nauka. Technologia. Jakość, 2014, 2 (93), s. 236.

${ }^{28}$ Rocznik Statystyczny Rzeczpospolitej Polskiej 2015. Główny Urząd Statystyczny, Warszawa 2016, s. 308; Mały rocznik statystyczny Polski, Główny Urząd Statystyczny, Warszawa 2016, s. 167.

${ }^{29}$ Wyka J., Lipiec K., Mazurek D., Bułynko J.: Wartość energetyczna pieczywa i jej zmiany w trakcie przechowywania. Bromat. Chem. Toksykol. - XLVIII, 2015, 1, s. 20.
} 
Zaspokajanie potrzeb konsumpcyjnych $\mathrm{w}$ opinii badanych kierowników gospodarstw domowych to podstawa zaspokajania wszelkich potrzeb członków gospodarstwa. Zdecydowanie mniej ważne było zaspokajanie potrzeb $\mathrm{w}$ zakresie dostarczania odzieży i obuwia, czy wyposażenia w sprzęty AGD i RTV. Przeprowadzone badania terenowe wskazały, iż pomimo ważności artykułów żywnościowych dla realizacji potrzeb członków gospodarstw domowych dobra te są marnotrawione $\mathrm{w}$ gospodarstwach. $\mathrm{W}$ badanych gospodarstwach domowych znaczącą metodą uporania się z nadmierną ilością żywności jest jej wyrzucanie do śmieci (ponad $60 \%$ gospodarstw stosuje tę formułę).

Analizując postawy gospodarstw domowych względem środowiska przyrodniczego można zaobserwować, iż $\mathrm{w}$ przypadku gospodarstw charakteryzujących się prośrodowiskową postawą zdecydowanie częściej nadmiar żywności oddawany jest innym na tle innych grup gospodarstw.

Uzyskane wyniki wskazuja, iż występuje ciągła potrzeba poszerzania wiedzy i świadomości konsumentów w zakresie problematyki środowiskowej, konsumpcji zrównoważonej. Jednocześnie wydaje się zasadne prowadzenie dalszych badań, które pozwoliły określić na ile świadomość ekologiczna zarówno kierownika gospodarstwa domowego, jak również pozostałych członków gospodarstwa wpływa na podejmowane decyzje konsumpcyjne. Zarówno w kontekście nabywania artykułów żywnościowych jak również innych dóbr na rynku.

\section{Bibliografia}

Bąk T.: Freeganizm jako subkultura i zjawisko nowych wartości w zglobalizowanym świecie, Edukacja Humanistyczna, nr 1 (30), 2014

Bilska B., Grzesińska W., Tomaszewska M., Rudziński M.: Marnotrawstwo żywności jako przykład nieefektywnego zarządzania w gospodarstwach domowych, Stowarzyszenie Ekonomistów Rolnictwa i Agrobiznesu, Roczniki Naukowe, Tom XVII, Zeszyt 4

Budżety gospodarstw domowych w 2016r. Informacje i opracowania statystyczne, Główny Urząd Statystyczny, Warszawa 2017

Cieślińska M., Kowrygo B.: Budowanie pozycji rynkowej i zdobywanie przewagi konkurencyjnej na przykładzie Danone sp. z o.o., Handel Wewnętrzny 2013;4(345)

Czubała A., Rola konsumentów w realizacji koncepcji społecznej odpowiedzialności przedsiębiorstw, Konsumpcja i rozwój, nr 1/2011

Dach Z. (red.): Wprowadzenie do ekonomii, Wydawnictwo Akademii Ekonomicznej w Krakowie, Kraków 1999

Dąbrowska A., Bylok F., Janoś-Kresło M., Kiełczewski D., Ozimek I.: Kompetencje konsumentów. Innowacyjne zachowania. Zrównoważona konsumpcja, Polskie Wydawnictwo Ekonomiczne, Warszawa 2015, s. 83.

Dąbrowska A., Janoś-Kresło M.: Marnowanie żywności jako problem społeczny, Handel Wewnętrzny 2013;4(345)

Gałązka M.: Społeczno-demograficzne uwarunkowania kształtowania się wydatków żywnościowych w gospodarstwach domowych w Polsce, Rocz. Nauk Rol., seria G, t. 100, z. 1, 2013

Kapusta F.: Bezpieczeństwo żywnościowe polski i jej mieszkańców w okresie przedakcesyjnym i po akcesji do Unii Europejskiej, Ekonomia XXI wieku, 4(12), 2016

Mały rocznik statystyczny Polski, Główny Urząd Statystyczny, Warszawa 2016

Kwasek M.: Zrównoważona konsumpcja żywności sposobem na zmniejszenie 
marnotrawstwa żywności, dostęp z dnia 14 luty 2017 https://www.ierigz.waw.pl/download/19559dr_hab._M._Kwasek.pdf

Obiedzińska A.: Wybrane aspekty zapewnienia bezpieczeństwa żywnościowego w Unii Europejskiej, Studia BAS Nr 4(48) 2016

Rocznik Statystyczny Rzeczpospolitej Polskiej 2015, Główny Urząd Statystyczny, Warszawa 2016

Siedlecka A.: Sustainable Consumption as a Behaviour Model of Households, Economic Science for Rural Development Conference Proceedings, No 45, 2017

Siedlecka A., Impact of the activities of local government on the quality of life of households, in the opinion of the inhabitants, of the border commune, Hanna, Miscellanea Geographica. Volume 19 , Issue 4

Śmiechowska M., Zrównoważona konsumpcja a marnotrawstwo żywności, Ann. Acad. Med. Gedan. 2015, 45

The State of Food Insecurity in the World. Meeting the 2015 international hunger targets: taking stock of uneven progress, FAO, Rome 2015

Ustawy z dnia 14 grudnia 2012 o odpadach, Dz.U. 2013 poz. 21, z póź. zmianami.

Wrzosek M., Bilska B., Kołożyn-Rajewska D., Krajewski K., Kondraszuk A.: Określenie skali i przyczyn strat żywności w handlu detalicznym na przykładzie mleka i jego przetworów, Żywność. Nauka. Technologia. Jakość, 2014, 2 (93)

Wspólna Polityka Rolna jako europejska polityka żywnościowa, Fundacja Programów Pomocy dla Rolnictwa Sekcja Analiz Ekonomicznych Polityki Rolnej, FAPA, Warszawa 2011

Wyka J., Lipiec K., Mazurek D., Bułynko J.: Wartość energetyczna pieczywa i jej zmiany w trakcie przechowywania, Bromat. Chem. Toksykol. - XLVIII, 2015, 1

Zalega T.: Freeganizm - nowy trend konsumencki w zachowaniach nabywczych miejskich gospodarstw domowych w Polsce w okresie kryzysu (wyniki badań), Zarządzanie innowacyjne w gospodarce i biznesie, $\mathrm{nr} 1(16) / 2013$

Zalega T.: Spożycie żywności $\mathrm{w}$ gospodarstwach domowych $\mathrm{z}$ osobami bezrobotnymi w województwie mazowieckim, Zeszyty Naukowe SGGW w Warszawie. Ekonomika i Organizacja Gospodarki Żywnościowej, 2011, nr 93

\section{Summary}

The aim of the paper is to indicate differences in the approach to sustainable consumption and food wastage according to the declared consumerist attitude. To accomplish such an aim there are asked the following research questions: Do households managed by respondents who express the opinion on the relationship between sustainable consumption and the state of the environment much less frequently discard food products? Do these types of households make more rational purchase decisions?

Key words: household, consumption, sustainable consumption, food wastage

Informacje o autorach:

Dr Agnieszka Siedlecka

Katedra Ekonomii i Zarządzania

Wydział nauk Ekonomicznych i Technicznych

Państwowa Szkoła Wyższa im. Papieża Jana Pawła II w Białej Podlaskiej

e-mail: a.siedlecka@dydaktyka.pswbp.pl

mgr Michal Kuszneruk

Katedra Ekonomii i Zarządzania

Wydział nauk Ekonomicznych i Technicznych

Państwowa Szkoła Wyższa im. Papieża Jana Pawła II w Białej Podlaskiej 